\title{
MEASURING THE IMPACT OF FACTORS AFFECTING REVERSE E-LOGISTICS' PERFORMANCE IN THE ELECTRONIC INDUSTRY IN LEBANON AND SYRIA
}

\author{
Mohamad AL Majzoub \\ Vilnius Gediminas Technical University, Lithuania \\ E-mail: mohamad_al_majzoub@hotmail.com \\ Vida Davidavičienè \\ Vilnius Gediminas Technical University, Lithuania \\ E-mail: vida.davidaviciene@vgtu.lt \\ Ieva Meidute-Kavaliauskiene \\ Vilnius Gediminas Technical University, Lithuania \\ E-mail: ieva.meidute@gmail.com
}

Submission: 1/22/2020

Revision: 2/15/2020

Accept: 2/20/2020

\section{ABSTRACT}

Reverse e-logistics has proven to have high significance in terms of profits, customer satisfaction, competition, and performance's efficiency. However, several firms in the Business-to-Consumer (B2C) e-commerce field, especially in developing countries such as those in the Middle East, still neglect its importance for the survival of the firm because they don't know how to improve reverse e-logistics (REL) performance. Therefore, the objective of this article is to identify the main factors that impact reverse e-logistics' performance and to analyze their effect. The methods used in this article are: scientific literature review, synthesis, questionnaires, and structural equation modelling. The study is done in Lebanon and Syria with a sample of 459 companies in the electronic industry who are engaged in $\mathrm{B} 2 \mathrm{C}$ e-commerce and is faced with reverse elogistics' challenges. The estimated results prove the significant impact of the identified factors: customer satisfaction, guarantee, and organization structure on reverse e-logistics' performance, which in turn has a significant impact on the efficiency of the performance of B2C companies engaged in reverse e-logistics activities as well.

Keywords: reverse logistics; e-commerce; B2B; B2C; factors; electronic sector; e-logistics 
ISSN: $2236-269 X$

DOI: 10.14807/ijmp.v11i6.1254

\section{INTRODUCTION}

Overall, the value of the global e-logistics market was USD 4 trillion in 2013, or about 10 percent of global GDP (WU et al., 2017). Among the top regions that are growing tremendously in B2C e-commerce, is the Asia-Pacific area, including the Middle East, which recorded an increase of 23\% in B2C e-commerce utilization in 2014 (XU et al., 2016). Thus, creating opportunities for established and existing firms to consider this area more and to invest in it. In 2016, there were more than 2.5 billion B2C e-commerce consumers in the world, yielding on average 2671 billion USD, among which is 1057 billion USD contributed AsiaPacific region and the Middle East, giving it a top position among other regions (CHOI; MAI, 2018).

In 2013, reverse e-logistics' costs accounted for a range between 800 million to $\$ 1$ billion, and these numbers are expected to grow tremendously (MAHINDROO et al., 2018). In 2015, the costs of reverse e-logistics' were about 130.6 billion USD and 223.6 billion USD for Asia-pacific and EMEA regions, respectively. Moreover, the returned products' costs for retailers recorded was about $\$ 260$ billion for the same year (MORGAN et al., 2018). Returned products represent more than 35\% of the total e-commerce retailers' cost (HUANG et al., 2015).

The good news is that when REL is implemented correctly, will lead to better resources' efficiency, and thus lower costs and higher profits (GAMBOA; RIVEROS, 2019). Statistics had shown that reducing costs form REL operations alone, account for at least $10 \%$ improvement in profits for an organization (SANGWAN, 2017). Moreover, the effective implementation of REL will lead to higher customer satisfaction (PANIGRAHI et al., 2018). The problem is preventing REL from happening is almost impossible. Moreover, measuring and improving performance of REL is highly complicated and difficult (EUCHI et al., 2019).

Despite the fact that some firms have already implemented effective measures to improve REL performance, yet there are numerous firms, especially in the Middle East, that weren't able to enhance REL activities because they don't know how. Limited knowledge exist about specific factors affecting REL performance, and whether focusing on such factors will enhance REL performance. There is scarcity in scientific researches in the field of REL's performance measurement, globally and precisely in the Middle East, where most firms still struggle in the logistics’ field. 
INDEPENDENT JOURNAL OF MANAGEMENT \& PRODUCTION (IJM\&P)

http://www.ijmp.jor.br

v. 11, n. 6, September - October 2020

ISSN: 2236-269X

DOI: 10.14807/ijmp.v11i6.1254

Thus, this study is conducted in Lebanon, and Syria. It involves 459 companies in the electronic industry that perform reverse e-logistics. The objective of this study is to determine the most important factors that impact REL performance of reverse e-logistics and to see whether enhancements in such factors will in turn lead in enhancement in REL performance, and thus better companies’ performance.

Thereby, the following research question (RQ) is imposed: What are the factors that affect the performance of reverse e-logistics and to what extent do REL activities affect the companies' performance? The methods used in this study are, literature review, synthesis, comparison analysis, and survey method manifested by online questionnaires, using google forms that were sent to the electronic companies in the REL field and the structural equation modelling (SEM) was used to analyze the data using Amos software.

\section{REVIEW OF LITERATURE}

The Development of ICT generated new possibilities for organizations management, and is becoming more and more potent in the economic sector. Therefore, it is vital to understand its significance as an innovative tool to communicate with consumers (BARROSO et al., 2019; DAVIDAVIČIENE் et al., 2017).

Application of ICT in business created opportunities and advantages, yet on the other hand it created new challenges for business organizations as well. Exchange of information, buying and selling products through the internet have become common in today's business transactions. Several people joining virtual groups, organizations and networks for business development reasons, and utilizing such opportunities a lot (DAVIDAVIČIENĖ et al., 2019; MERKEVIČIUS et al., 2015).

Such progression in ICT lead to the development of E-commerce business, especially B2C e-commerce, that in turn lead to expansion of e-logistics. E-logistics is the process of implementing diverse logistics' activities from dealing with manufacturers, distributors, logistics hubs, to dealing with consumers through using the internet (SKITSKO, 2016). After the huge expansion of e-logistics, some products ordered online had to be returned for different purposes such as: reutilize, fix, renovate, recycle, and prefabricate, or either completely discarded, and this is known as REL or reverse e-logistics (EUCHI et al., 2019).

Reverse e-logistics is the process of implementing all diverse activities of reverse logistics (RL) electronically. In other words, reverse e-logistics is the information and communication technology (ICT) empowered form of reverse logistics (KHAN et al., 2012). 


\section{INDEPENDENT JOURNAL OF MANAGEMENT \& PRODUCTION (IJM\&P)}

http://www.ijmp.jor.br

v. 11, n. 6, September - October 2020

ISSN: 2236-269X

DOI: 10.14807/ijmp.v11i6.1254

The latter was created after the progress of internet, information and computer technology, and the wide utilization of electronic presentation of information within information logistics (SKITSKO, 2016).

REL is a series of processes in which different kinds of products, whether defected or wrong or for the sake of recycling, are assimilated from users to the producer's profitability (GAMBOA; RIVEROS, 2019). REL concept goes back to the earliest 90s, where several countries noticed the importance of taking care of the environment and its natural resources, which in turn will yield profits if resources were used wisely. REL offered the opportunity to recycle, discard hazardous or normal products, or reuse them efficiently, and this pulled out the attention of both manufacturers and researchers (RACHIH et al., 2019).

At that the Council of Logistics Management (CLM) that stated that REL is the planning, implementing, and controlling the efficient use of resources/products to get from consumers to manufacturers in a cost-effective manner (ROGER; TIBBEN-LEMBKE, 1998). REL's significance is not related only to increasing profits, but also to better competing position, efficiency in performance, and customer satisfaction (YOGI, 2015; HUANG et al., 2015; EUCHI et al., 2019; AGRAWAL et al., 2016; GAMBOA; RIVEROS, 2019; SANGWAN, 2017; MAHINDROO et al., 2018; MORGAN et al., 2018).

REL's costs are 9.5\% of the supply chain cost (SANGWAN, 2017), sometimes reaching $\$ 1$ billion (MAHINDROO et al., 2018). Moreover 35\% of e-commerce products are returned for different reasons (HUANG et al., 2015). Today's dynamic environment and the fast technological pace leave no room for REL mistakes because the price will be big. The problem is that REL can't be completely prevented, and at the same time it is full of complications due to its complex working systems (SUDARTO et al., 2017). Thus fast, efficient, and effective solutions in REL are required to better meet customers' needs (EUCHI et al., 2019). Complications of REL constantly requires the existence of original, creative, efficient and costeffective solutions (AL MAJZOUB; DAVIDAVIČIENE், 2019).

In today's e-commerce business, the success of e-logistics' can't be achieved with the effective implementation of REL systems. That is both forward and backward movements in the supply chain should be taken into consideration (KAZEMI et al., 2018). In the previous years, the focus on important aspect to increase companies' performance such as efficient use of resources, better competition, higher market share and profits, emphasized a greater attention in the field of REL interest (BAI; SARKIS, 2019). 
DOI: 10.14807/ijmp.v11i6.1254

\subsection{Reverse E-Logistics’ Performance Factors Evaluation}

The most important factors that might have a direct impact on REL performance, and which were emphasized by scholars and experts in the field, will be discussed further.

- Third-party reverse logistics provider (3PRLP): Choosing the optimal 3PRLP in terms of both costs and effectiveness, is central in the REL processes application. The sustainability of the supply chain resources' and REL performance are highly dependent on the good selection of 3PRLP, which gave it even a more important role than before (BAI; SARKIS, 2019). Outsourcing REL activities to 3PRLP is favored especially when the firms realize the difficulty of REL processes, and/or there exists a state of scarcity in resources (LI et al., 2018). Numerous partners are needed to cooperate competently to attain best REL performance (TOSARKANI; AMIN, 2018). Thus, reverse logistics' outsourcing to a 3rd party is increasing tremendously due to its huge importance in that field (SREMAC et al., 2018). To enhance REL performance, then the attention should be drawn to the proper implementation of third-party logistics (SANGWAN, 2017).

- Organizational Structure: The impact of organizational structure is high on REL performance (MORGAN et al., 2018). Organizational structure positively affects REL performance when it is done correctly. However, if the firm is faced with a bad structure then it will be considered as a barrier to the efficient performance of REL. For instance, a firm that doesn't provide its working staff with continuous training and education, will have a poor REL performance (SIRISAWAT; KIATCHAROENPOL, 2016). An organization structure impact's level on REL performance depends on its own rules, guidelines, protocols, and cooperation ambiance between its managers and employees (WAQAS et al., 2018). Sometimes the performance of REL is affected by the bull-whip effect of stock's level consistency if the organization structure used can't accurately forecast the order rate and inventory rate (CANNELLA et al., 2016). As a matter of fact, organizational structure has one of the most potent impact on REL, which in turn REL has a high dependency on it to achieve better results (YADAV; BARVE, 2015).

- Infrastructure: Infrastructure can be explained in diverse terms. It could be in terms of the facilities such as storage areas, equipment and transportation (SIRISAWAT; KIATCHAROENPOL, 2016). It also extend to include electricity, roads, maintenance, industry, forecasting planning, and systems to control returned products (PRAKASH; 
DOI: 10.14807/ijmp.v11i6.1254

BARUA, 2015). Firms that have problems in their infrastructure means that they have problems in managing returned or recalled goods, thus a problem in REL (SIRISAWAT; KIATCHAROENPOL, 2016). Thus if a firm has good infrastructure, then it should be able to manage returned products efficiently. However, its absence will impact company's capability to manage these returns thus will cause way less profits (PRAKASH; BARUA, 2015).

A company's infrastructure is fundamentally connected to its supply chain. The infrastructure is a part of diverse logistical activities including the REL, which can't be completed without the convenient infrastructure (MORGAN et al., 2018). A bad technology and infrastructure will be considered as a barrier not only for REL development but to the entire firm as well (GOVINDAN; BOUZON, 2018). REL is driven by infrastructure and technology, which cause enormous challenge manifested by a deficient logistical system. A common example would be in the developing countries where transport infrastructure is extremely poor including bad roads, this resulted in huge truck maintenance expenses and freight damage (BOUZON et al., 2015). Thus, a convenient infrastructure that takes into consideration resources' efficiency must be selected if a firm wishes to have an efficient REL system (YOGI, 2015). Therefore, an effective REL systems can’t be reached without a proper firm's infrastructure (CHINDA, 2017).

- Guarantee: There exist several reasons for customers to return goods, among them is warranty which in turn plays a significant impact on REL (PANDIAN; ABDULKADER, 2017). Warranties can result in bigger amounts of repairs and returned goods, thus affecting REL processes (HUANG et al., 2015). However, not granting a good guarantee to customers will cause problems as well since they will not be reassured to buy the product in the first place (EUCHI, et al., 2019). Numerous businesses started integrating the reverse e-logistics strategies with their companies' strategies and supply chain because a big number of returns is due to warranty returns (YOGI, 2015). Firms manage REL differently especially when it comes to warranty of products since it continuously impacts their sales (PANIGRAHI et al., 2018).

- Inventory management: Companies that are not willing to outsource, have to deal strategically with inventory management since this in turn will impact REL performance as well (VLACHOS, 2016). An organized, efficient, and well-controlled 
DOI: 10.14807/ijmp.v11i6.1254

REL can in turn yield huge savings in terms of costs, and better inventory management as well (AGRAWAL et al., 2016).

Forecasting methods aid in determining and in preparing the approximate amounts of inventory level and when done correctly can yield an acceptable inventory turnover rate, yet uncertainty seems always to exist. In the presence of REL, good inventory management will improve its efficiency (YOGI, 2015). It was proved that management awareness of the importance of having a good inventory control is an indispensable part to enhance capabilities of REL (PANIGRAHI et al., 2018). Several studies showed that the higher the return products are, the lower is the bullwhip effect. However, other studies proved that the stability of inventory management is enhanced when the amount of recollected goods increase as well (CANNELLA et al., 2016).

- Customer Service. In order to obtain a good customer service, firms must know as indicated before the expenses of its inventory in order not to fall in the shortage or surplus trap (YOGI, 2015). The concentration on a better REL systems, initiated in turn the concentration on having a good customer service since the latter will yield in more sales thus enhancing the whole supply chain (LINTON et al., 2007). Customer service is the delivery of goods to customers in a way that differentiates the firm's values using good logistics' management, and which result in customer satisfaction and logistics management. Customer service is now even way more than before impacting REL and the entire organizations, due to its significant relevancy to customer satisfaction (COOPER et al., 2016).

The most captivating feature of excellent customer service is that every customer demands different remarkable service. This explains the importance of the entire supply chain in doing so, including REL that must cooperate to ensure the customer's needs are met (OCHOCKA, 2019). Customer service is the minimum service that a customer expects to obtain during any purchase. Thus, in case of returning a product through REL, he/she expects to see a good service as well (ASIAN et al., 2019). Despite the fact that several firms utilize the diverse social media platforms for e-commerce, yet they overlook that importance of a good customer service that if disappears will lead to returning products and thus increase REL (DAUGHERTY et al., 2019).

\subsection{Performance Measurement of REL}


INDEPENDENT JOURNAL OF MANAGEMENT \& PRODUCTION (IJM\&P)

http://www.ijmp.jor.br

v. 11, n. 6, September - October 2020

ISSN: 2236-269X

DOI: 10.14807/ijmp.v11i6.1254

Performance measurement is very crucial for a firm aiming to reaching its goals, and putting better competitive strategies (YOGI, 2015). Only few authors discussed how REL performance measurement can be done due to its complexity (SHAIK; ABDUL-KADER, 2018; YOGI, 2015; AGRAWAL et al., 2016; PANDIAN; ABDUL-KADER, 2017). Perhaps, the best way to measure performance of REL is measuring four important points: RL cycle time, network capacity, transportation capacity, and recovery efficiency rate (YOGI, 2015). From another perspective, taking into consideration the economic and profit programs, technology, corporate social responsibility programs can be used as well to measure REL performance (DA SILVEIRA GUIMARÃES; SALOMON, 2015).

In every firm, the need of certain competencies are required to measure REL performance. Criteria such as the financial, environmental, innovation, meeting diverse stake holder needs, and social criteria are usually potent indicators used in the measurement process (SHAIK; ABDUL-KADER, 2018). Triple bottom approach is a very popular one in measuring REL performance. It relies on taking into consideration three aspects the economic, environmental, and social performance in addition to their relative sub- criteria that help in further analysis (AGRAWAL et al., 2016).

Performance measurement can also be done in terms of lead time, input and output quantities, and stimulating agents. These agents represented are mainly the gatherer, provider, supplier, reproducer, and recycler agents (PANDIAN; ABDUL-KADER, 2017). The complexity of REL performance measurement necessitates taking into consideration indicators that facilitate this process. Indicators such as a good green and environmental image, flexibility in recycling or fixing defected products, good quality products, responsiveness rates, costs, and revenues all can be used to measure REL performance (SIRISAWAT; KIATCHAROENPOL, 2016).

Over the past few years, the most frequently criteria utilized in the performance process of REL are: information and communication, management, technology, and social commerce. For the social commerce in prospect, it has four important sub-criteria the: reviews, quality control, customer relationship management, and utilization risk (HAN; TRIMI, 2018). However, two very important aspects that are often neglected in REL measurement performance are the commitment to efficiency when using resources, and the frequency of returned goods (MAHINDROO et al., 2018). 
INDEPENDENT JOURNAL OF MANAGEMENT \& PRODUCTION (IJM\&P)

http://www.ijmp.jor.br

v. 11, n. 6, September - October 2020

ISSN: $2236-269 X$

DOI: 10.14807/ijmp.v11i6.1254

Performance measurement of REL is the way of estimating the efficiency of the total activities related to REL. Efficiency here refers to meeting the customers' needs at the lowest cost possible, however at the same time reaching customer satisfaction (EUCHI et al., 2019). Firms seeking opportunities for a better market position should strive to excel in measuring performance in terms of environmental, economic, and controlling (HUANG et al., 2015).

Evaluating and measuring the degree of a firm's enhancement on important REL outcomes such technology implementation, distribution period, inventory quantities, and maximum capacity usage, all will lead to a sustainable REL and thus a sustainable supply chain (MORGAN et al., 2018). Brief, REL performance enhancement can't be reached without enhancing environmental, economic, and social aspects, since they are positively related to REL performance (BAL; SATOGLU, 2018; SUDARTO et al., 2017).

\subsection{Performance Measurement of companies' efficiency}

Evaluating companies’ performance is heavily impacted by the REL performance. Several authors explained how a firm can measure its performance. One famous method to measure companies' efficiency is the balanced scorecard (BSC), by which the firms can indicate the overall performance and where improvement can be made (SHAIK; ABDULKADER, 2018). Commitment to resources' efficiency is a key indicator for a good performance (YOGI, 2015).

Despite the fact that the efficient use of resources' is used in REL performance measurement, nonetheless it is used for companies' performance as well (MAHINDROO et al., 2018). Resources' efficiency mixed with a low cost is sometimes sufficient for an effective performance measurement (EUCHI et al., 2019). Efforts to enhance firms’ performance alone might negatively affect the entire supply chain thus leading to catastrophic results.

Performance's measurement can be done through measuring of financial and marketing results. As a matter of fact, for an efficient measurement of companies' performance, a company should take into consideration not only the financial capital, but the physical capital, and operational capacity as well (JIANU et al., 2017). In order to do a proper assessment of companies' performance related to reverse e-logistics, a firm should definitely consider performance characteristics such as product lifecycle, market strategies, procedures, and firm's production and monitoring capabilities (WANG et al., 2019).

Effective companies' performance management should not be done without a good supply chain management measurement, which can be done in terms of cost saving and 
DOI: 10.14807/ijmp.v11i6.1254

operational efficiency (YADAV; BARVE, 2015). Forming of Omni-channels can be effective as well. These channels include assessment of assimilation of procedure, information stream, and inventory turn-over rate (ANG; TAN, 2018). Performing the capacity planning in both an efficient and flexible manners is a potent indicator for companies' performance (SUDARTO et al., 2017).

Indicators such as a firm's financial performance, market competition, use of technology, and employment satisfaction, are used by logistic firms to measure their competencies in the market field of their domain (CHINDA, 2017). Considering financial and lowering costs indicator for efficient companies' performance is important, however neglecting the stakeholder's satisfaction might hurt a company's performance (GOVINDAN; BOUZON, 2018). Actually, REL itself contributes to the firm's performance financially. Thus, taking care of REL means taking care of firm's performance as well since they are directly linked (LARSEN et al., 2018).

A beneficial way in measuring performance would be the use of key performance indicators for the various cost incurred over a specific period of time. For instance, measuring before and after effect of implementing efficient REL in terms of collection costs and energy savings (SANGWAN, 2017). From another perspective, evaluation performance should be done as a triple way framework: the strategic, tactical and operational into a cost-benefit analysis manner (PANDIAN; ABDUL-KADER, 2017).

Focusing on reduction of consumption of resources varying from decreasing energy consumption to less utilization of resources, is an indispensable part of an efficient firm's performance (WANG et al., 2018). Nonetheless, operational performances' cost should also be included in that evaluation processes (MORGAN et al., 2018). The first thing a firm needs to is to identify the diverse scales of finance, stakeholders, procedures both in-house and outhouse, and novelty to be used as a competitive edge (BOUZON et al., 2015).

Standards in quality of goods or services quality, in addition to costs' measurement, are good indicators to measure a firm's performance (LI et al., 2018). Other firms rely heavily on using the Net Present Value (NPV) as a sole indicator to measure the economic performance of a firm, and for them this is the most important factor that should be studied and monitored (BOGATAJ; GRUBBSTRÖM, 2013).

\section{METHODOLOGY}


DOI: 10.14807/ijmp.v11i6.1254

As stated earlier, the aim of this research is to identify the most potent factors affecting REL performance, and the effect of REL activities on the companies' performance. Therefore, the research question that was imposed earlier is that: What are the factors that affect the performance of reverse e-logistics and to what extent do REL activities affect the companies' performance. Thus, after identifying the most potent six factors that might be affecting REL performance, the next step is to validate the following hypotheses that were formulated based on the analysis made from the literature review part, and from the imposed research question.

After determining the factors that might be affecting reverse e-logistics, the next step is to verify these factors by first developing the following hypotheses:

- H1: Customer satisfaction positively correlated to REL performance

- H2: Inventory management is positively correlated to REL performance

- H3: Bad infrastructure is negatively correlated to REL performance

- H4: Organization structure is positively correlated to REL performance

- H5: Guarantee is positively correlated to REL performance

- H6: Ineffective third party is negatively correlated to REL performance

- H7: REL performance is positively correlated to the efficiency of company's performance.

- H7-a: REL performance is positively correlated with the company's profits

- H7-b: REL performance is positively correlated with resources’ efficiency

- H7-c: REL performance is positively correlated with operational capacity

Thus, the next step is to validate by accepting or rejecting the above hypotheses, by using questionnaires and SEM through Amos software.

Concerning the questionnaire, it was a five-point Likert scale one that was sent to 682 e-commerce companies in Lebanon and Syria and that perform e-commerce and consequently reverse e-logistics. The questionnaire is made up of a total of 35 questions, out of which 10 are demographics and 25 asking about reverse e-logistics’ performance in the company. A total of 561 were returned, and after excluding the ones that do not perform reverse e-logistics answers, the total was 459 answers (67.30\% response). A five-point Likert scale was used (1=strongly disagree, $2=$ =disagree, $3=$ =neutral, $4=$ =agree, $5=$ =strongly agree) to do the analysis. 
DOI: 10.14807/ijmp.v11i6.1254

As a validation to the questionnaire, Cronbach's alpha value was applied. Concerning Cronbach's alpha value, it ranges from 0 to 1 ; the higher values propose greater internal reliability. The, alpha value from 0.70 and above indicates reliability. This is the case in all of the above variables except for employees, but it is still in the acceptable range. This means that the results for the latent variables under study are reliable. The recorded alpha values are summarized in Table 1 below.

Table 1: Cronbach's alpha of latent variables

\begin{tabular}{|l|l|}
\hline Latent Variable & Cronbach's alpha \\
\hline Customer satisfaction & 0.740 \\
\hline Inventory management & 0.798 \\
\hline Bad infrastructure & 0.700 \\
\hline Organization structure & 0.768 \\
\hline Guarantee & 0.796 \\
\hline Ineffective third party & 0.735 \\
\hline
\end{tabular}

Concerning the validity of sample size adequacy of data that were used in factor analysis, two tests were used for that purpose: the Kaiser-Meyer-Olkin (KMO) and Bartlett's. These tests were used because they are the most popular tests used for measuring adequacy of sampling size and data. KMO implies significance if it is more than 0.5 and here $\mathrm{KMO}=0.721$, whereas the Bartlett's test value significance must be less than 0.5 and here Bartlett's test= 0.000 , which again gives reliability to the factors under study. This shows that the compulsory adequacy level is met.

Using AMOS software, we were able to build the model to test our theories. The model is depicted in Figure 1 below. Based on the analysis data generated from AMOS, the estimates calculated and their relative significances are summarized in table

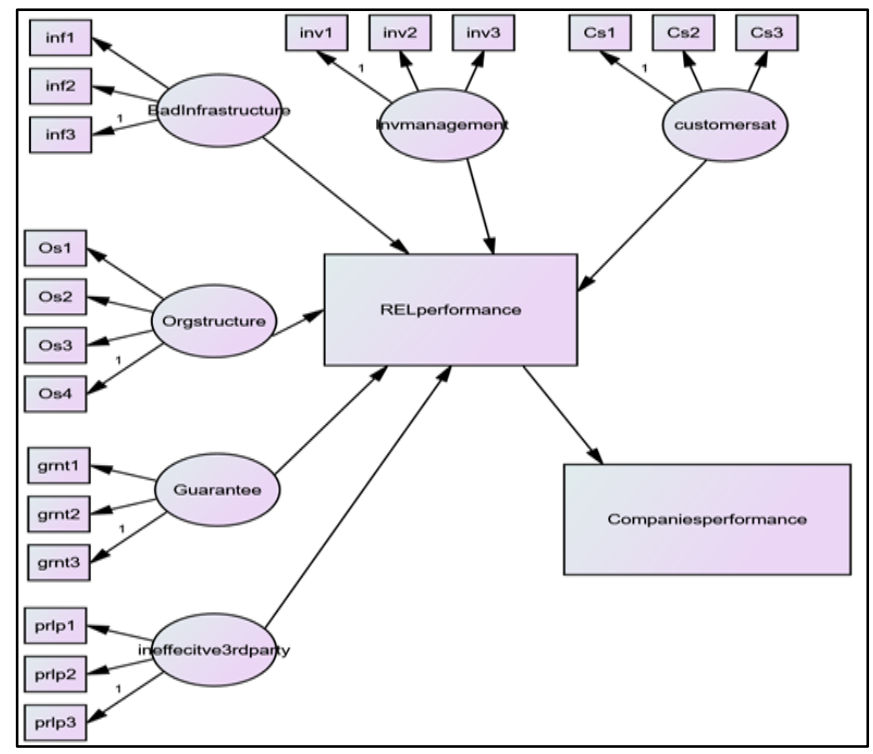

Figure 1: The empirical data model 
DOI: 10.14807/ijmp.v11i6.1254

Using AMOS software, we need to test the model fit. Table 2 below illustrates the important indicators that explains if there is a model fit or not.

Table 2: Model fit data

\begin{tabular}{|l|l|l|l|l|l|l|l|l|l|}
\hline Model & CMIN & DF & CMIN/DF & P & CFI & GFI & RMSEA & SRMR & Pclose \\
\hline Default Model & 227.529 & 170 & 1.338 & 0.000 & 0.975 & 0.955 & 0.027 & 0.042 & 1.000 \\
\hline
\end{tabular}

- CMIN: refers to the chi-square for the model is also called the discrepancy function, usually CMIN should be divided by DF (degree of freedom) to analyze model fit. The CMIN/DF should be between 1 and 3, and here it is 1.338, which indicates first model fit.

- CFI: refers to the comparative fit index, compares the fit of our model to that of the independent variables. This fit contributes to the difference among the observed and predicted covariance matrices. CFI should be greater than 0.950 for a good model fit, and here it is the case where $\mathrm{CFI}=0.975$.

- GFI: refers to the goodness-of-fit index, which is a measure of fit between the hypothesized model and the observed covariance matrix. GFI should be greater than 0.90 to indicate the existence of model fit, in our study GFI $=0.955$, which indicates a good model fit.

- RMSEA: The root mean square error of approximation, is used as a mechanism for adjusting for sample size where chi-square statistics are used. It is implemented as a supplement to the chi-square fit tests. RMSEA should be less than 0.06, and here this is the case since RMSEA $=0.027$.

- SRMR: Standardized Root Mean Square Residual; first it indicates if there is any missing values in the data. , and second it indicates the square root of the discrepancy between the sample covariance matrix and the model covariance matrix. SRMR should be less than 0.08 , in our study SRMR= 0.042 which is less than 0.08 .

- Pclose: a p value for examining the null hypothesis that the sample where RMSEA is no greater than 0.05 . It gives an idea about the test of close fit, while $\mathrm{P}$ value gives an idea about the test of exact fit. Pclose should be greater than 0.05 to indicate a good measure fit index, and it's the case here since Pclose $=1.000$.

All of the above indicators prove that the empirical data fit with the model, thus our model is fit and can be used to test our hypotheses. Thus, the model fitness indicates that the results that will be shown later will be considered as valid, since the absence of model fitness 
DOI: 10.14807/ijmp.v11i6.1254

will give the results and values no importance at all, even if $\mathrm{P}$ value was below 0.05 . Therefore, the managerial approach that will be taken will be considered as effective due to this model fitness.

\section{DISCUSSION OF RESULTS}

After making sure that the model fits, now the estimates of the factors affecting REL should be calculated and analyzed. The estimates which are summarized in table 3 and table 4 , give us an idea about the correlation between the variables understudy with REL performance.

Table 3: Estimates of factors affecting reverse e-logistics

\begin{tabular}{|l|l|l|}
\hline Factors effect on REL & Estimate & P-value \\
\hline Customer satisfaction & 0.100 & $0.038^{*}$ \\
\hline Inventory management & 0.58 & 0.199 \\
\hline Bad infrastructure & -0.108 & $0.033^{*}$ \\
\hline Organization structure & 0.624 & $* *$ \\
\hline Guarantee & 0.123 & $0.013^{*}$ \\
\hline Ineffective third party & -0.78 & 0.132 \\
\hline \multicolumn{2}{|r|}{$* *$ P-value $<0.1$, *P-value $<0.05$}
\end{tabular}

An estimate between 0 and 0.3 is considered weak positive correlation, between 0.3 and 0.6 is moderate positive, and 0.6 and 1 indicates a strong positive correlation. Thus, customer satisfaction, guarantee, and inventory management, have a weak positive correlation with REL performance. Moreover, Organization structure has a strong positive correlation with REL performance. For all those factors who have a positive correlation, this means that if a firm improve these factors, they will result in an improvement in REL performance. Concerning the other two factors, Bad infrastructure, and ineffective third party, they have a weak negative correlation. This means that these factors will result in bad REL performance.

Table 4: Impact of REL on other factors

\begin{tabular}{|l|l|l|}
\hline REL effect on other factors & Estimate & P- value \\
\hline profits & .490 & $* * *$ \\
\hline resources' efficiency & .521 & $* * *$ \\
\hline operational capacity & .479 & $* * *$ \\
\hline Overall companies' performance & .397 & $* * *$ \\
\hline \multicolumn{2}{|c|}{$* * *$ P-value $<0.1,{ }^{*}$ P-value $<0.05$}
\end{tabular}

Concerning the impact of REL performance on the efficiency of companies' performance: profits, resources' efficiency, and operational capacity, all have moderate positive correlation with increasing companies' performance. This means that if REL performance of a company is improved, it will result in better performance of the company as a whole.

Based on the above information, now we can see if our first 6 hypotheses are accepted or rejected. 
DOI: 10.14807/ijmp.v11i6.1254

First, Hypothesis 1, Customer satisfaction positively correlated to REL performance (estimate $=0.038, \mathrm{p}<0.05$ ), is accepted. It means that if the firm is able to maintain high customer satisfaction, then the REL performance will improve.

Hypothesis 2, inventory management is positively correlated to REL performance (estimate $=0.58, \mathrm{p}>0.05$ ), is rejected. This means that if a firm has good management of its own inventory, then the REL performance will increase. However, since the $\mathrm{P}$ value is greater than 0.05, this hypothesis can’t be supported.

Hypothesis 3, bad infrastructure is negatively correlated to REL performance (estimate $=-0.108, \mathrm{p}<0.05$ ), is accepted. This means that if a firm has a bad infrastructure, it will not be able to improve its REL performance.

Hypothesis 4, organization structure is positively correlated to REL performance (estimate $=0.624, \mathrm{p}<0.05$ ), is accepted. This means that the organization structure can directly affect REL performance, so the firm should be working in the optimal structure if it wishes to improve its REL performance.

Hypothesis 5, guarantee is positively correlated to REL performance (estimate $=0.123$, $\mathrm{p}<0.05$ ), is accepted. This indicates that when a firm grants its customers a good guarantee, then they will be more reassured to buy from them, which in turn will lead to improved REL performance.

Hypothesis 6, ineffective third party is negatively correlated to REL performance (estimate $=-0.78, \mathrm{p}>0.05$ ), is rejected. It means that when a firm deals with bad partners in providing third party reverse logistics, the REL performance will be deteriorated. However, due to the p value that is large than 0.05 , it can't be indicated as significant conclusion.

Concerning the second part of our study, which is summarized in Hypothesis 7, it states that REL performance is positively correlated with companies' performance efficiency (estimate $=0.397, \mathrm{p}<0.05$ ), is accepted. This hypothesis is divided into three consequent hypotheses.

Hypothesis 7-a: REL performance is positively correlated with the company's profits (estimate $=0.490, \mathrm{p}<0.05$ ), is accepted. This means that REL performance, when improved, can increase the company's profits.

Hypothesis 7-b: REL performance is positively correlated with resources' efficiency (estimate $=0.521, \mathrm{p}<0.05$ ), is accepted. This means that good REL performance will result in 
INDEPENDENT JOURNAL OF MANAGEMENT \& PRODUCTION (IJM\&P)

http://www.ijmp.jor.br

v. 11, n. 6, September - October 2020

ISSN: 2236-269X

DOI: 10.14807/ijmp.v11i6.1254

an efficient use of resources, that is to say improved REL performance will increase the resources' efficiency and thus firm's resources will be less used, and this again will yield increased profits.

Finally, Hypothesis 7-c: REL performance is positively correlated with operational capacity (estimate $=0.479, \mathrm{p}<0.05$ ), is accepted. This indicates that improved REL performance will result in improved operational capacity.

The whole hypothesis and their relative analysis are summarized in Table 5 below.

Table 5: Summarized results of the hypotheses

\begin{tabular}{|l|l|l|l|}
\hline Hypothesis & Estimate & P-value & Accept/Reject \\
\hline $\begin{array}{l}\text { H1: Customer satisfaction positively correlated to REL } \\
\text { performance }\end{array}$ & 0.100 & $0.038^{* *}$ & Accept \\
\hline $\begin{array}{l}\text { H2: Inventory management is positively correlated to } \\
\text { REL performance }\end{array}$ & 0.58 & 0.199 & Reject \\
\hline $\begin{array}{l}\text { H3: Bad infrastructure is negatively correlated to REL } \\
\text { performance }\end{array}$ & -0.108 & $0.033^{* *}$ & Accept \\
\hline $\begin{array}{l}\text { H4: Organization structure is positively correlated to } \\
\text { REL performance }\end{array}$ & 0.624 & $* * *$ & Accept \\
\hline $\begin{array}{l}\text { H5: Guarantee is positively correlated to REL } \\
\text { performance }\end{array}$ & 0.123 & $0.013^{* *}$ & Accept \\
\hline $\begin{array}{l}\text { H6: Ineffective third party is negatively correlated to } \\
\text { REL performance }\end{array}$ & -0.78 & 0.132 & Reject \\
\hline $\begin{array}{l}\text { H7: REL performance is positively correlated to the } \\
\text { efficiency of company's performance. }\end{array}$ & 0.397 & $* * *$ & Accept \\
\hline $\begin{array}{l}\text { H7-a: REL performance is positively correlated with the } \\
\text { company's profits. }\end{array}$ & 0.490 & $* * *$ & Accept \\
\hline $\begin{array}{l}\text { H7-b: REL performance is positively correlated with } \\
\text { resources' efficiency. }\end{array}$ & 0.521 & $* * *$ & Accept \\
\hline $\begin{array}{l}\text { H7-c: REL performance is positively correlated with } \\
\text { operational capacity. }\end{array}$ & 0.479 & $* * *$ & Accept \\
\hline
\end{tabular}

Thus, by focusing on the accepted hypotheses, firms doing B2C e-commerce companies that are facing REL challenges, should take all of the customer satisfaction, infrastructure, organization structure, and guarantee factors into consideration if they wish to enhance REL performance. From the other side, improved REL performance will result in improved profits, resources’ efficiency, and operational capacity.

A head to head to comparison between Lebanese and Syrian companies showed that these two countries share a lot of similarities in term of factors affecting their REL performance. For instance the factors: customer satisfaction, infrastructure, organization structure, and guarantee have proven to impact REL activities for both countries. This could be as a result of similar consumers’ behaviors due to very close cultures among them. 
INDEPENDENT JOURNAL OF MANAGEMENT \& PRODUCTION (IJM\&P)

http://www.ijmp.jor.br

v. 11, n. 6, September - October 2020

ISSN: 2236-269X

DOI: 10.14807/ijmp.v11i6.1254

However, certain differences exists between the two countries, such as the kind of items purchased in the electronics industry. For example, the most ordered products in Lebanon were mainly mobile phones, and sports equipment such as treadmills, whereas in Syria the most ordered products were laptops and tablets.

\section{CONCLUSION}

In today's technological advancement, B2C e-commerce is progressing very fast and number of companies engaging in such transactions is increasing tremendously. However B2C e-commerce faces many challenges, and perhaps the most important and complicated one is the reverse e-logistics' ones, which is often neglected. The good news is that due to its huge importance, reverse e-logistics is an indispensable part of a company's supply chain that can result in huge benefits to the company such as increased profits, and better competing position.

In the first part of our study we determined the most important factors that impact REL performance. A sum of four factors were concluded that are significantly and positively correlated with REL performance. These factors are: customer satisfaction, organization structure, infrastructure and guarantee. Thus for a firm wishing to enhance the REL performance, it should take these factors into consideration and work on enhancing them, since they will result in an improved REL performance.

The second part of our study, we tested the impact of REL on the efficiency of companies' performance. We found that there was a significant and positive correlation between improved REL performance and efficiency of company's performance. These enhancements in the company's performance were enhancements in terms of profits, efficiency of resources' used, and better operational capacity as well. This concludes that if a firm increases the REL performance, it will result in benefits to the entire company and not only enhancements through its supply chain.

Research limitations faced in Syria, was the difficulty in communicating highly with the firms operating there due to the war that is currently occurring in the country. In Lebanon, the infrastructure still lacks a lot of development to encourage B2C e-commerce, especially the problems in the internet connection that has a relatively very slow speed compared to other countries in the Middle East. Moreover, several follow-up emails had to be sent for companies in both countries to encourage them to fill up the questionnaires. Indeed, a total of 682 questionnaires were sent and the ones returned were only 459, despite following up with them on a regular basis. 
INDEPENDENT JOURNAL OF MANAGEMENT \& PRODUCTION (IJM\&P)

http://www.ijmp.jor.br

v. 11, n. 6, September - October 2020

ISSN: 2236-269X

DOI: 10.14807/ijmp.v11i6.1254

Developing countries, including the Middle East still lack a lot of academic researches and findings. Thus, our future research recommendation is to emphasize more the importance of doing such researches not only in Lebanon and Syria, but also in the Middle East where there is a lack of scientific findings in the field of reverse e-logistics. These countries should be considered as opportunities for B2C e-commerce business since there is a huge chance to occupy this market and increase profits for firms operating in B2C field. Finally, the factors mentioned above are not exhaustive, thus other factors mentioned in our previous studies and by other scientific scholars should be also considered in future research for testing.

\section{REFERENCES}

AGRAWAL, S.; SINGH, R. K.; MURTAZA, Q. (2016) Triple bottom line performance evaluation of reverse logistics. Competitiveness Review, v. 26, n. 3, p. 289-310. DOI: 10.1108/CR-04-2015-0029.

AL MAJZOUB, M.; DAVIDAVIČIENĖ, V. (2019) Comparative analysis of reverse elogistics' solution in Asia and Europe. In: International Scientific Conference On Contemporary Issues In Business, Management And Education, Proceedings, https://doi.org/10.3846/cibmee.2019.091, Vilnius: CIBMEE, 2019.

ANG, A.; TAN, A. (2018) Designing reverse logistics network in an Omni-channel environment in Asia, Logforum, v. 14, n. 4, p. 519-533. DOI: 10.17270/J.LOG.2018.307

ASIAN, S.; POOL, J.; NAZARPOUR, A.; TABAEEIAN, R. (2019) On the importance of service performance and customer satisfaction in third-party logistics selection: An application of Kano model. Benchmarking: An International Journal, v. 26, n. 5, p. 15501564. DOI: 10.1108/BIJ-05-2018-0121

BAI, C.; SARKIS, J. (2019) Integrating and extending data and decision tools for sustainable third-party reverse logistics provider selection. Computers and Operations Research, v. 110, p. 188-207. DOI: 10.1016/j.cor.2018.06.005.

BAL, A.; SATOGLU, S. I. (2018) A goal programming model for sustainable reverse logistics operations planning and an application. Journal of Cleaner Production, v. 201, p. 1081-1091. DOI: 10.1016/j.jclepro.2018.08.104 .

BARROSO, R. M. R.; FERREIRA, F. A. F.; MEIDUTE்-KAVALIAUSKIENĖ, I.; BANAITIENĖ, N.; FALCÃO, P. F.; ROSA, Á. A. (2019) Analyzing the determinants of ecommerce in small and medium-sized enterprises: a cognition driven framework.

Technological and economic development of economy, v. 25, n. 3, p. 496-518. DOI: 10.3846/tede.2019.9386.

BOGATAJ, M.; GRUBBSTRÖM, R. W. (2013) Transportation delays in reverse logistics. International Journal of Production Economics, v. 143, n. 2, p. 395-402. DOI: 10.1016/j.ijpe.2011.12.007.

BOUZON, M.; SPRICIGO, R.; RODRIGUEZ, C. M. T.; DE QUEIROZ, A. A.; CAUCHICK, M. P. A. (2015) Reverse logistics drivers: Empirical evidence from a case study in an emerging economy. Production Planning and Control, v. 26, n. 16, p. 13681385. DOI: 10.1080/09537287.2015.1049239. 
CANNELLA, S.; BRUCCOLERI, M.; FRAMINAN, J. M. (2016) Closed-loop supply chains: What reverse logistics factors influence performance? International Journal of Production Economics, v. 175, p. 35-49. DOI: 10.1016/j.ijpe.2016.01.012

CHINDA T. (2017) Examination of Factors Influencing the Successful Implementation of Reverse Logistics in the Construction Industry: Pilot Study. Procedia Engineering, v. 182, p. 99-105. Available: https://www.sciencedirect.com/science. Access: 20th January, 2020. DOI: 10.1016/j.proeng.2017.03.128 .

CHOI, Y.; MAI, D. Q. (2018) The sustainable role of the e-trust in the B2C e- commerce of Vietnam, Sustainability, v.10, n.1, p. 1-18. DOI: 10.3390/su10010291.

COOPER, A. L.; HUSCROFT, J. R.; OVERSTREET, R. E.; HAZEN, B. T.(2016) Knowledge management for logistics service providers: The role of learning culture. Industrial Management and Data Systems, v. 116, n. 3, p. 584-602. DOI: 10.1108/IMDS06-2015-0262.

DA SILVEIRA GUIMARÃES, J. L.; SALOMON, V. A. P. (2015) ANP applied to the evaluation of performance indicators of reverse logistics in footwear industry. Procedia Computer Science, v. 55, p. 139-148. DOI: 10.1016/j.procs.2015.07.021.

DAUGHERTY, P.; BOLUMOLE, Y.; GRAWE, S. (2019) The new age of customer impatience: An agenda for reawakening logistics customer service research. International Journal of Physical Distribution \& Logistics Management, v. 49, n. 1, p. 4-32. DOI: 10.1108/IJPDLM-03-2018-0143

DAVIDAVIČIENĖ, V.; MEIDUTE்-KAVALIAUSKIENĖ, I.; PALIULIS, R. (2019) Research on the influence of social media on generation Y consumer purchase decisions. Marketing and management of innovations, n. 4, p. 39-49. DOI: 10.21272/mmi.2019.4-04.

DAVIDAVIČIENĖ, V.; PABEDINSKAITE, A.; DAVIDAVIČIUS, S. (2017) Social networks in B2B and b2c communication. Transformations in Business and Economics, $v$. 16, n. 1, p. 69-84.

EUCHI, J.; BOUZIDI, D.; BOUZID, Z. (2019) Structural analysis of acute success factors of performance of reverse logistics relative to customer satisfaction, International Journal of Combinatorial Optimization Problems and Informatics, v. 10, n. 2, p. 39-56.

GAMBOA, A. C. D.; RIVEROS, B. F. A. (2019) Data Envelopment Analysis to measure relative performance based on key indicators from a supply network with Reverse Logistics. Inge Cuc, v. 14, n. 8, p. 137-146. DOI: 10.17981/ingecuc.14.2.2018.13

GOVINDAN, K.; BOUZON, M. (2018) From a literature review to a multi-perspective framework for reverse logistics barriers and drivers. Journal of Cleaner Production, v. 187, p. 318-337. DOI: 10.1016/j.jclepro.2018.03.040 .

HAN, H.; TRIMI, S. (2018) A fuzzy TOPSIS method for performance evaluation of reverse logistics in social commerce platforms. Expert Systems with Applications, v. 103, p. 133145. DOI: 10.1016/j.eswa.2018.03.003 .

HUANG, Y. C.; RAHMAN, S.; WU, Y. C. J.; HUANG, C. J. (2015) Salient task environment, reverse logistics and performance. International Journal of Physical Distribution and Logistics Management, v. 45, n. 9, p. 979-1006. DOI: 10.1108/IJPDLM08-2014-0182. 
JIANU, I.; JIANU, I.; TURLEA, C. (2017) Measuring the company’s real performance by physical capital maintenance. Economic Computation and Economic Cybernetics Studies and Research, v. 51, n. 1, p. 37-57.

KAZEMI, N.; MODAK, N. M.; GOVINDAN, K. (2018) A review of reverse logistics and closed loop supply chain management studies published in IJPR: a bibliometric and content analysis. International Journal of Production Research, v. 1, n. 24, p. 4937-4960. DOI: 10.1080/00207543.2018.1471244.

KHAN, S.; KHAN, F.; ZHANG, B. (2012) Reverse e-Logistics for SMEs in Pakistan. In: WU Y. (eds) Software Engineering and Knowledge Engineering: Theory and Practice. Advances in Intelligent and Soft Computing, v. 115, Springer, Berlin, Heidelberg.

LARSEN, S.; MASI, D.; FEIBERT, D.; JACOBSEN, P. (2018) How the reverse supply chain impacts the firm's financial performance: A manufacturer's perspective. International Journal of Physical Distribution \& Logistics Management, v. 48, n. 3, p. 284-307. DOI:10.1108/IJPDLM-01-2017-0031.

LI, Y. L.; YING, C. S.; CHIN, K. S.; YANG, H. T.; XU, J. (2018) Third-party reverse logistics provider selection approach based on hybrid-information MCDM and cumulative prospect theory. Journal of Cleaner Production, v. 195, p. 573-584. DOI: 10.1016/j.jclepro.2018.05.213 .

LINTON, J. D.; KLASSEN, R. D.; JAYARAMAN, V. (2007) Sustainable supply chains: an introduction. Journal of Operations Management, v. 25, n. 6, p. 1075-1082. DOI: 10.1016/j.jom.2007.01.012.

MAHINDROO, A.; SAMALIA, H. V.; VERMA, P. (2018) Moderated influence of return frequency and resource commitment on information systems and reverse logistics strategic performance. International Journal of Productivity and Performance Management, $v$. 67, n. 3, p. 550-570. DOI: 10.1108/IJPPM-05-2016-0101

MERKEVIČIUS, J.; DAVIDAVIČIENĖ, V.; RAUDELIUNIENE, J.; BULECA, J. (2015) Virtual organization: Specifics of creation of personnel management system. $\mathbf{E}+\mathbf{M}$ Ekonomie a Management, v. 18, n. 4, p. 200-211. DOI: 10.15240/tul/001/2015-4-014.

MORGAN, T. R.; TOKMAN, M.; RICHEY, R .G. (2018) Resource commitment and sustainability: a reverse logistics performance process model. International Journal of Physical Distribution \& Logistics Management, v. 48, n. 2, p. 164-182. DOI: 10.1108/IJPDLM-02-2017-0068

OCHOCKA, J. (2019) Mobile technologies in logistic customer service as a tool for winning customers' satisfaction. Scientific Journal of Logistics, v. 15, n. 3, p. 403-411. DOI: 10.17270/J.LOG.2019.338

PANDIAN, G. R. S.; ABDUL-KADER, W. (2017) Performance evaluation of reverse logistics enterprise-an agent-based simulation approach. International Journal of Sustainable Engineering, v. 10, n. 6, p. 384-398. DOI: 10.1080/19397038.2017.1370032.

PANIGRAHI, S. K.; KAR, F. W.; FEN, T. A.; HOE, L. K.; WONG, M. (2018) A Strategic Initiative for Successful Reverse Logistics Management in Retail Industry. Global Business Review, v. 19, n. 3, p. 151-175. DOI: 10.1177/0972150918758096

PRAKASH, C.; BARUA, M. K. (2015) Integration of AHP-TOPSIS method for prioritizing the solutions of reverse logistics adoption to overcome its barriers under fuzzy environment. Journal of Manufacturing Systems, v. 37, p. 599-615. DOI: 10.1016/j.jmsy.2015.03.001. 
RACHIH, H.; MHADA, F. Z.; CHIHEB, R. (2019) Meta-heuristics for reverse logistics: A literature review and perspectives. Computers and Industrial Engineering, v. 27, p. 45-62. DOI: 10.1016/j.cie.2018.11.058

ROGER, D.; TIBBEN-LEMBKE, R. (1998) Going backwards: Reverse logistics trends and practices. Reno, Nevada: Reverse Logistics Executive Council.

SANGWAN, K. S. (2017) Key Activities, Decision Variables and Performance Indicators of Reverse Logistics. Procedia CIRP, v. 6, n. 1, p. 257-262. Available: https://www.sciencedirect.com/science. Access: 19th January, 2020. DOI:10.1016/j.procir.2016.11.185

SHAIK, M. N.; ABDUL-KADER, W. (2018) A hybrid multiple criteria decision making approach for measuring comprehensive performance of reverse logistics enterprises.

Computers and Industrial Engineering, v. 123, p. 9-25. DOI: 10.1016/j.cie.2018.06.007

SIRISAWAT, P.; KIATCHAROENPOL, T. (2016) Correlation of barriers to reverse logistics performance using structural equation modeling. In: IEEE International Conference on Industrial Engineering and Engineering Management, Proceedings, https://doi.org/10.1109/IEEM.2016.7797853, Bali: IEEE, 2016.

SKITSKO, V. I. (2016) E-logistics and m-logistics in information economy. Logforum, v. 12, n. 1, p. 7-16. DOI: 10.17270/J.LOG.2016.1.1

SREMAC, S.; STEVIĆ, Ž.; PAMUČAR, D.; ARSIĆ, M.; MATIĆ, B. (2018) Evaluation of a third-party logistics (3PL) provider using a rough SWARA-WASPAS model based on a new rough dombi aggregator. Symmetry, v. 10, n. 8, p. 1-25. DOI: 10.3390/sym10080305.

YOGI, K. (2015) Performance evaluation of reverse logistics: A case of LPG agency. Cogent Business and Management, v. 2, n. 1, p. 1-17. DOI: 10.1080/23311975.2015.1063229

SUDARTO, S.; TAKAHASHI, K.; MORIKAWA, K. (2017) Efficient flexible long-term capacity planning for optimal sustainability dimensions performance of reverse logistics social responsibility: A system dynamics approach. International Journal of Production Economics, v. 190, p. 45-59. DOI: 10.1016/j.ijpe.2017.06.017

TOSARKANI, B. M.; AMIN, S. H. (2018) A multi-objective model to configure an electronic reverse logistics network and third party selection, Journal of Cleaner Production, v. 198, p. 662-682. DOI: 10.1016/j.jclepro.2018.07.056

VLACHOS, I. P. (2016) Reverse logistics capabilities and firm performance: the mediating role of business strategy. International Journal of Logistics Research and Applications, v. 19, n. 5, p. 424-442. DOI: 10.1080/13675567.2015.1115471

WANG, F.; YU, Y.; WANG, X.; REN, H.; SHAFIE-KHAH, M.; CATALÃO, J. P. S. (2018) Residential electricity consumption level impact factor analysis based on wrapper feature selection and multinomial logistic regression. Energies, v. 11, n. 5, p. 1-26. DOI: 10.3390/en11051180.

WANG, H.; JIANG, Z.; ZHANG, H.; WANG, Y.; YANG, Y.; LI, Y. (2019) An integrated MCDM approach considering demands-matching for reverse logistics. Journal of Cleaner Production, v. 208, p. 199-210. DOI: 10.1016/j.jclepro.2018.10.131 .

WAQAS, M.; DONG, Q.-L.; AHMAD, N.; ZHU, Y.; NADEEM, M. (2018) Critical barriers to implementation of reverse logistics in the manufacturing industry: A case study of a developing country. Sustainability, v. 10, n. 11, p. 1-25. DOI: 10.3390/su10114202 
WU, Y. C.; GOH, M.; YUAN, C. H.; HUANG, S. H. (2017) Logistics management research collaboration in Asia. International Journal of Logistics Management, v. 28, n. 1, p. 206223. DOI: 10.1108/IJLM-09-2013-0104

XU, Y.; ZHANG, X.; CAO, J.; CHEN, Y.; YE, X. (2016) Collaboration and Evolution of ECommerce and Express Delivery Industry Supply Chain. Discrete Dynamics in Nature and Society, p. 1-12, DOI: 10.1155/2016/3452037.

YADAV, D. K.; BARVE, A. (2015) Analysis of critical success factors of humanitarian supply chain: An application of Interpretive Structural Modeling. International Journal of Disaster Risk Reduction, v. 12, p. 213-225. DOI: 10.1016/j.ijdrr.2015.01.008. 